\title{
THE PROPORTION OF CERTAIN IMPORTANT INORGANIC CONSTITUENTS IN THE DYING HEART MUSCLE
}

By L. C. SCOTT

(From the Heart Station, New Orleans Charity Hospital, and the Department of Tropical Medicine, Tulane University, New Orleans)

(Received for publication June 28, 1930)

Careful survey of the literature does not reveal many examinations of the cardiac muscle for inorganic elements. As a matter of fact I have only been able to discover one analysis of the human heart which makes any pretension to a detailed series of determinations, by Lematte et al. (1) and this apparently was only on one heart. These investigators determined the percentages of alkali and alkaline earth metals, phosphoric acid, iron, and dry residue, and reported their results in the form of the hydroxides of sodium, potassium, calcium, and magnesium.

Determinations of potassium and sodium have been recently made on human heart and skeletal muscle by Harrison, Pilcher, and Ewing (2). Norn (3) also gives a series of potassium and sodium determinations made on the human dog and ox heart. Matthews (4) presents some figures on the inorganic constituents in his textbook. Aside from these few, efforts to trace other analyses complete or partial have so far failed.

Among these earlier workers who laid the foundation for our present knowledge of physiological action of potassium, sodium and calcium the noteworthy are Howell (5) and Ringer (6). Zwaardemaker (7) has within recent years extended and developed the earlier investigations of Howell and Ringer paying especial attention to the activity of potassium.

That the quantity and proportions of the inorganic constituents of the muscle are vitally important to its activity is self-evident and that within limits they will vary from individual to individual in health and disease is a reasonable assumption. Maxima and minima as well 
as optimum proportions have been frequently demonstrated in amphibian hearts by Zwaardemaker and others; the questions arise just what amounts in the human hearts are compatible with life and continuous function, and how do they vary in disease? Qualified answers can only be given in terms of arithmetical means which are equivalent to generalities for the reason that rarely is any death free from contributory causes that make classification at best only an approximation. Nevertheless the determination of the average proportions of the important inorganic elements in diseased cardiac muscle cannot be without interest, and with this object in view the analyses were made.

The results are believed to be accurate and dependable. On fresh hearts a total of 69 analyses were made, eleven however, for water, ash, sodium and potassium only, since the relation of other elements was considered to have been sufficiently well established with the first 58 analyses.

A large number of the alkali determinations were discarded because of probable inaccuracy. The later ones were made with a modified technique, checks having shown these results to be within the limits of experimental error.

Analyses include the determination of water, ash, $\mathrm{P}_{2} \mathrm{O}_{5}, \mathrm{Fe}_{2} \mathrm{O}_{3}, \mathrm{CaO}$, $\mathrm{MgO}, \mathrm{K}_{2} \mathrm{O}$, and $\mathrm{Na}_{2} \mathrm{O}$. The alkalies are expressed in terms of oxides for the sake of uniformity.

\section{METHOD}

Segments of the left ventricle of the hearts were cleared of epicardium and blood vessels and passed through a meat grinder.

Water. Two portions of this ground material were weighed out in beakers. Either 31 or 34 grams were taken in order to obtain from five to seven grams of dry substance. These portions were dried gradually, beginning at about $85^{\circ} \mathrm{C}$. and increasing to $100^{\circ} \mathrm{C}$. for several days until a relatively constant weight was obtained. Constant weight to better than $5 \mathrm{mgm}$. was hardly obtainable within a reasonable time, nor was the result appreciably modified by even greater differences. Ammonia salts are probably responsible for this difficulty. Alternate heating and drying in a vacuum was tried with but little better success. The duplicate determinations usually agreed well to the second decimal place.

$A s h$ was determined by igniting 5 or 6 grams and in later determinations 10 grams of dried pulverized muscle in a silica dish at as low a temperature as possible, and keeping the contents just at red heat until white. In this way melting to- 
gether of the salts was prevented, and while it is usually impossible to completely free the ash of carbon, the amount is so small as hardly to effect the percentage. The majority of these determinations were made in duplicate with 5 to 6 gram quantities, but in later analyses for potassium and sodium alone with only one portion of 10 grams. The addition of sulphuric acid as suggested by Norn (3) or of nitric acid was not found to be of assistance in destroying organic matter.

Phosphoric acid. The ash from 5 to 6 grams of dried heart muscle tissue was then taken up with strong nitric acid, evaporated to dryness, redissolved in 20 to $25 \mathrm{cc}$. of 25 per cent nitric acid, $20 \mathrm{cc}$. of 34 per cent ammonium nitrate solution was added, the contents of the beaker heated to boiling, and the phosphates precipitated with hot 30 per cent ammonium molybdate solution added slowly from a pipette. The precipitate of ammonium phospho-molybdate was filtered off and washed with dilute ammonium nitrate solution. It was then dissolved on the filter with ammonium hydroxide and precipitated with magnesium chloride solution and the $\mathrm{P}_{2} \mathrm{O}_{5}$ determined from the $\mathrm{Mg}_{2} \mathrm{P}_{2} \mathrm{O}_{7}$ according to the method of Woy described by Treadwell (8). Reduction of the phospho-molybdate and titration with standard permanganate solution gave good results but was not employed as a routine method.

The slight excess of ammonium molybdate appears not to influence any of the later determinations. The removal of the molybdenum is very tedious and the possibility of loss of other elements during the numerous manipulations incident to the removal is in no wise compensated for by subsequent ease in handling the solution.

Iron was estimated in the filtrate from the phosphates by the addition of ammonium hydroxide.

Calcium was precipitated in the filtrate from the ferric hydroxide with a few drops of 15 per cent ammonium oxalate solution. The amount of lime is small and it is necessary to heat for some time with occasional stirring and to wait until the calcium oxalate has completely settled before filtering off. The calcium oxalate was ignited to $\mathrm{CaO}$ and weighed as such.

Magnesium is precipitated in the filtrate from the calcium oxalate with slight excess of 15 per cent ammonium phosphate solution. It is necessary to stir very thoroughly until the solution begins to cloud and then to add approximately one fifth volume of strong ammonium hydroxide to insure complete precipitation. Standing over night facilitates this separation. Duplicate determinations almost invariably agree very closely.

Potassium and sodium were determined either by using the ash from 5 to 6 grams of dried material or of that from 10 grams. In both instances solution of the ash was affected with strong $\mathrm{HCl}$, the solution evaporated to dryness, and again dissolved in a few drops of $\mathrm{HCl}$. It was then diluted with water made alkaline with $\mathrm{NH}_{4} \mathrm{OH}$ and stirred thoroughly. Milk of lime according to the suggestion of Goto (9) or 25 per cent calcium chloride solution to completely precipitate the phosphates and finally ammonium oxalate to get rid of the excess of lime were added. The beaker was allowed to stand at least 2 to 3 hours, preferably over 
night. In this manner all lime, iron, phosphates, calcium, and magnesium are eliminated and nothing remains in solution but ammonium and alkali metal salts.

From this point on the method of Finkner-Neubauer (8) which reference to Neubauer's (10) original work shows to be extremely accurate was used for the determination of potassium and sodium.

When 5 to 6 grams of dried muscle were used for the determination, the filtrate from the precipitate containing the other elements was acidified with sulphuric acid, evaporated and heated to remove excess of acid and ammonium sulphate. The residue was then heated to constant weight using solid ammonium carbonate and the resultant sulphates weighed.

Where 10 gram quantities of dried muscle were employed the procedure was the same except that dilution was first made to $250 \mathrm{cc}$. in a volumetric flask and $25 \mathrm{cc}$. quantities equivalent to 1 gram of the original were measured out for each determi-

TABLE 1

Control of method of analysis

Calculated: Sulphates from 0.1 gram $\mathrm{NaCl}$ and 0.1 gram $\mathrm{KCl}=0.2383$ gram; platinum from 0.1 gram $\mathrm{KCl}=0.1314$ gram

\begin{tabular}{c|c|c|c|c}
\hline Number & Sulphates & Platinum & $\mathrm{KCl}$ & $\mathrm{NaCl}$ \\
\cline { 2 - 3 } & grams & grams & grams & grams \\
2 & 0.2370 & 0.1316 & 0.1002 & 0.0986 \\
3 & 0.2382 & 0.1290 & 0.0982 & 0.1005 \\
4 & 0.2348 & 0.1314 & 0.1000 & 0.0970 \\
5 & 0.2378 & 0.1316 & 0.1002 & 0.0992 \\
6 & 0.2368 & 0.1316 & 0.1002 & 0.0984 \\
\cline { 1 - 2 } Average....... & 0.2358 & 0.1296 & 0.0987 & 0.0991 \\
\hline
\end{tabular}

nation. In this way three or more determinations could conveniently be made on each heart.

The mixed sulphates were dissolved in a small amount of water with the addition of a few drops of $\mathrm{HCl}$. This solution should be perfectly clear; turbidity is indicative of incomplete removal of phosphates. Excess of platinum chloride is then added, and the filtration and reduction of the chloro-platinate carried out according to Neubauer. The factors used for the conversion of the platinum into its equivalents were 0.4811 for $\mathrm{K}_{2} \mathrm{O}, 0.7612$ for $\mathrm{KCl}$ and 0.8905 for $\mathrm{K}_{2} \mathrm{SO}_{4}$.

These manipulations are tedious but have the merit of considerable accuracy. Trials with known quantities of $\mathrm{KCl}$ and $\mathrm{NaCl}$ gave sufficiently good results. The tables of Neubauer show that when notable quantities of lime, magnesium and sodium salts or excess of platinum chloride, or sulphuric acid, were added to solutions, the estimation of the potassium contained in it was not markedly affected. The method of Kramer and Tisdall (11) determining potassium with 
sodium cobaltinitrite or the application of Kramer and Gittleman's (12) gas measurement method employed by Harrison, Pilcher and Ewing (2) is doubtless more convenient but can hardly be more accurate than this old established platinum method.

The series of six consecutive determinations of $\mathrm{KCl}$ and $\mathrm{NaCl}$ in a mixture of the salts were made without any special precautions and in Pyrex glass vessels as were all those on the cardiac muscle (see table 1).

The main difficulty is encountered with mixed sulphates. The compounds $\mathrm{K}_{2} \mathrm{~S}_{2} \mathrm{O}_{7}$ and $\mathrm{Na}_{2} \mathrm{~S}_{2} \mathrm{O}_{7}$ said to be produced by the sulphuric acid are not readily converted with ammonium carbonate to neutral sulphates from 0.2 gram of the mixed chlorides but this was very satisfactorily accomplished with the smaller quantities obtained from 1 gram of muscle tissue. There seems to be a tendency for the sodium to be low; the potassium usually checking very well. The potassium and sodium chlorides used were Baker and Adamson C.P. analyzed chemicals.

\section{RESULTS}

The hearts on which the determinations were made were utilized as quickly after autopsy as possible. They represent a large variety of diseases, of which those resulting from degenerative changes in the cardiovascular system were in the majority.

An attempt to classify the determinations was made, but owing to the fact that two or more diseases were commonly present at the same time, and the impracticability of working out worth while constants for the group, this arrangement has been abandoned for the present.

Table 2 contains a summary of 58 analyses for water, ash, phosphates, iron, calcium and magnesium, together with the results of 33 and 32 determinations respectively of potassium and sodium.

Another table (table 3) comprises the classification of the analyses according to the racial groups. It will be observed that there is no significant difference between white and colored individuals though the latter predominate. Unfortunately there are only four analyses on hearts from white persons available for comparison of the $\mathrm{K}_{2} \mathrm{O}$ and $\mathrm{Na}_{2} \mathrm{O}$ contents consequently the standard deviation and probable error have been omitted. Both of these factors have been computed for the other constituents by the usual statistical evaluation methods.

The deviation values are quite large as one would expect from hearts that have been subjected to toxic processes. It is to be deplored that determinations on normal cardiac muscle, at least on hearts of persons not dying of disease are not available for comparison, but it seems quite 
probable that even were it possible to always distinguish absolutely normal hearts variability in the constituents would likewise be found.

During the course of the work the percentage of $\mathrm{Na}_{2} \mathrm{O}$ was not

TABLE 2

Summary of analyses

(Percentages obtained on the basis of dry muscle tissue. Water excepted)

\begin{tabular}{|c|c|c|c|c|}
\hline Constituents & $\begin{array}{l}\text { Number of } \\
\text { hearts }\end{array}$ & Mean & $\begin{array}{l}\text { Probable error } \\
\text { of mean }\end{array}$ & $\begin{array}{l}\text { Standard } \\
\text { deviation }\end{array}$ \\
\hline & & per cent & & \\
\hline $\mathrm{H}_{2} \mathrm{O}$. & 58 & 80.130 & \pm 0.139 & 1.5690 \\
\hline Ash $\ldots \ldots \ldots \ldots$ & 58 & 4.509 & \pm 0.040 & 0.4506 \\
\hline $\mathrm{P}_{2} \mathrm{O}_{5} \ldots \ldots \ldots \ldots$ & 58 & 1.855 & \pm 0.021 & 0.2325 \\
\hline $\mathrm{Fe}_{2} \mathrm{O}_{3} \ldots \ldots \ldots \ldots \ldots \ldots$ & 58 & 0.085 & \pm 0.0032 & 0.0360 \\
\hline $\mathrm{CaO} \ldots$ & 58 & 0.071 & \pm 0.0035 & 0.0397 \\
\hline MgO. . & 58 & 0.137 & \pm 0.0018 & 0.0209 \\
\hline $\mathbf{K}_{2} \mathbf{O} \ldots \ldots \ldots$ & 33 & 1.101 & \pm 0.031 & 0.2666 \\
\hline $\mathrm{Na}_{2} \mathrm{O}$ & 32 & 1.191 & \pm 0.026 & 0.2145 \\
\hline
\end{tabular}

TABLE 3

Racial grouping

(Percentages on the basis of dry muscle tissue. Water excepted)

\begin{tabular}{|c|c|c|c|c|c|c|c|c|}
\hline \multirow[b]{2}{*}{ Constituents } & \multicolumn{4}{|c|}{ White } & \multicolumn{4}{|c|}{ Colored } \\
\hline & $\begin{array}{c}\text { Number } \\
\text { of } \\
\text { hearts }\end{array}$ & Mean & $\left|\begin{array}{c}\text { Probable } \\
\text { error of } \\
\text { mean }\end{array}\right|$ & $\begin{array}{l}\text { Stand- } \\
\text { ard de- } \\
\text { viation }\end{array}$ & $\begin{array}{c}\text { Number } \\
\text { of } \\
\text { hearts }\end{array}$ & Mean & $\begin{array}{c}\text { Probable } \\
\text { error of } \\
\text { mean }\end{array} \mid$ & $\begin{array}{l}\text { Stand- } \\
\text { ard de- } \\
\text { viation }\end{array}$ \\
\hline & & per cent & & & & per cent & & \\
\hline $\mathrm{H}_{2} \mathrm{O}$. & 17 & 80.090 & \pm 0.207 & 1.267 & 52 & 80.230 & \pm 0.142 & 1.521 \\
\hline Ash. . & 17 & 4.474 & \pm 0.070 & 0.429 & 52 & 4.564 & \pm 0.044 & 0.468 \\
\hline $\mathrm{P}_{2} \mathrm{O}_{5} \ldots$ & 16 & 1.771 & \pm 0.062 & 0.168 & 42 & 1.888 & \pm 0.025 & 0.245 \\
\hline $\mathrm{Fe}_{2} \mathrm{O}_{3} \ldots$ & 16 & 0.090 & \pm 0.006 & 0.034 & 42 & 0.084 & \pm 0.004 & 0.037 \\
\hline $\mathrm{CaO}$. & 16 & 0.091 & \pm 0.007 & 0.041 & 42 & 0.064 & \pm 0.004 & 0.039 \\
\hline MgO. . & 16 & 0.131 & \pm 0.003 & 0.016 & 42 & 0.139 & \pm 0.002 & 0.020 \\
\hline $\mathrm{K}_{2} \mathrm{O} \ldots$ & 4 & 0.926 & & & 29 & 1.125 & \pm 0.033 & 0.264 \\
\hline $\mathrm{Na}_{2} \mathrm{O}$ & 4 & 1.380 & & & 28 & 1.164 & \pm 0.026 & 0.204 \\
\hline
\end{tabular}

infrequently found to be in excess of the $\mathrm{K}_{2} \mathrm{O}$. There was no reason to doubt the accuracy of the determinations and the inversion of the usual relation occurs often enough to indicate that this is of some significance in the maintenance of cardiac contractility. (The proba- 
ble error of the mean in both tables has been calculated, using the formula

$$
\frac{0.6745 s}{\sqrt{N}}
$$

where $\mathrm{s}$ is the standard deviation of the observations and $N$ the number of observations.)

Another series of analyses was made on the ventricle and bundle of the ox heart (table 4). The results obtained on the bundle tissue cannot be regarded as better than approximate. The quantity, re-

TABLE 4

Ventricle and bundle of ox heart

(All percentages except water based on dried tissue)

\begin{tabular}{|c|c|c|c|c|c|c|c|c|}
\hline Specimen & Water & Ash & $\mathrm{P}_{2} \mathrm{O}_{6}$ & $\mathrm{Fe}_{2} \mathrm{O}_{2}$ & $\mathrm{CaO}$ & $\mathrm{MgO}$ & $\mathrm{K}_{2} \mathrm{O}$ & $\mathrm{Na}_{2} \mathrm{O}$ \\
\hline & per cent & per cent & per cent & per cent & per cent & per cent & per cent & per cent \\
\hline \multicolumn{9}{|l|}{ Ventricle: } \\
\hline No. 1. & 79.15 & 5.301 & 2.348 & 0.047 & 0.013 & 0.217 & 1.429 & 0.843 \\
\hline No. 2.. & 78.24 & 4.842 & & & & & 1.390 & 1.087 \\
\hline No. $3 \ldots \ldots \ldots \ldots \ldots \ldots$ & 78.92 & 5.200 & & & & & 1.479 & 1.188 \\
\hline \multicolumn{9}{|l|}{ Bundle: } \\
\hline No. $1 \ldots \ldots \ldots \ldots \ldots$ & 79.82 & 3.343 & & & & & 1.205 & 2.128 \\
\hline No. $2 \ldots \ldots \ldots \ldots \ldots \ldots$ & 74.89 & 4.500 & & & & & 1.202 & 0.928 \\
\hline
\end{tabular}

gardless of care in removal, is small and the chance of drying before proper weighing can be made considerable.

\section{DISCUSSION}

In a series of fifty-eight consecutive analyses of fresh hearts' constituents, water, ash, $\mathrm{P}_{2} \mathrm{O}_{5}, \mathrm{Fe}_{2} \mathrm{O}_{3}, \mathrm{CaO}$ and $\mathrm{MgO}$ have been found to exhibit considerable variation. The water content varies between a maximum of 84.91 per cent and a minimum of 77.21 per cent; the ash between 5.592 per cent and 3.532 per cent; the $\mathrm{P}_{2} \mathrm{O}_{5}$ between 2.468 and 1.278 per cent; the $\mathrm{Fe}_{2} \mathrm{O}_{3}$ between 0.153 and 0.030 per cent; the $\mathrm{CaO}$ between 0.250 and 0.020 per cent; the $\mathrm{MgO}$ between 0.187 and 0.074 per cent. The limits for the values found for $\mathrm{K}_{2} \mathrm{O}$ and 
$\mathrm{Na}_{2} \mathrm{O}$ in 33 analyses are between 1.768 and 0.740 per cent for $\mathrm{K}_{2} \mathrm{O}$ and between 1.760 and 0.740 per cent for $\mathrm{Na}_{2} \mathrm{O}$.

The variability is, however, more apparent than real. One has only to examine the columns of figures to gain the impression that there is a tendency to grouping within rather close limits. The least variable of all the constituents is the magnesium and this element is fairly constant regardless of disease. As already stated there appears not to be any correlation between age or disease and any of the constituents. Calcium, which might be expected to exceed in arteriosclerotic changes, is no higher proportionately than in the hearts of individuals dying of carcinoma; nor is age a factor in raising calcium values.

Anyone who has observed a large number of hearts cannot fail to wonder why an organ showing few if any macroscopic or microscopic pathological changes comes to a complete standstill, and, on the other hand, one is equally at a loss to explain how a small or large flabby anemic-looking heart with sclerotic changes or with perforated or stenotic valve flaps can maintain life as long as it does. Questions arise in the mind as to whether or not organic toxic products are entirely responsible for the cessation of cardiac rhythmicity and hence all life processes, or whether perhaps an imbalance between the inorganic constituents exists which is sufficient to cause death. Unfortunately, these analyses do not throw any light on the problem and from this standpoint do not afford the explanation it was hoped they would. Perhaps it is mainly because no accurate determinations of the inorganic constituents in a long series of "normal" hearts exist, such as might be obtained from healthy persons dying as the result of accidents. This would probably be the only means of determining the actual proportions of calcium, magnesium, potassium, and sodium salts indispensable to normal cardiac activity.

Some insight into the rôle played by calcium and potassium in heart tissue has been derived from the work of Ringer (6) and Howell (5) and their collaborators. The meticulous researches of Zwaardemaker (7) on the proportions of potassium necessary to maintain contractility and on the importance of the radioactivity of this element has opened up a new field of research. Furthermore, the investigations of Haberlandt, (13) and Demoor (14) and Zwaardemaker (15) on the "Herzhormon," "substance sensabilatrice" or "automatin," which 
according to $\mathrm{Zwaardemaker}$ is equivalent to, or at least bears a strong resemblance to, the vitamin $B$ of Eijkman are of interest. All the more is this so as Zwaardemaker has found that this substance is virtually inactive without having been first irradiated by some radioactive substance, or when the perfusing solution contains potassium. According to Zwaardemaker's work, the potassium gives off energy in the form of beta emanation, which is a vital necessity for the maintenance of cardiac rhythmicity.

That calcium, potassium, and sodium are to a greater or lesser degree antagonistic in their action on the cardiac mechanism is abundantly evident from the work of these men. This, of course, leads to the conclusion that for the maintenance of normal conditions there are optimal proportions of calcium, potassium, and sodium. That such an equilibrium must, of course, be maintained in the human heart equally as well as in the hearts of lower animals admits of no argument. It is therefore not impossible that many of the analyses for these necessary inorganic elements would if adequately interpreted reveal a disproportion among these elements incompatible with cardiac func. tion.

Examination of the cardiac tissue, using MacCallum's (16) method of demonstrating potassium in situ, was very satisfactory. There is no doubt that the larger proportion of the potassium salts is located within the intercellular spaces.

Employment of MacCallum's stain on sections of the auriculo-ventricular bundle of the ox heart appeared to show less potassium within the cells of the conducting tissue than within muscle cells of the ventricle, but this is uncertain for the moment. There is, however, no doubt that the connective tissue surrounding the conduction fibers was almost entirely lacking in potassium, which is sufficient to account for the lower percentage in the bundle than in the ventricular muscle.

The literature does not disclose any definite reason why magnesium is an invariable and apparently a necessary constituent of cardiac muscle tissue. Like calcium and sodium, it is probably not radioactive and there is no evidence that it is independently active or that it functions as an adjuvant to calcium in promoting tonicity. It does not seem to act as an antagonist to the alkali metals. It is conceivable that its value is that of stabilizer, moderating cardiac hyperirritability. 


\section{CONCLUSIONS}

1. A fairly large number of analyses of cardiac muscle from persons dying of a variety of diseases does not reveal any relation between the water content, ash, calcium, magnesium, potassium, and sodium content and age and disease.

2. The inorganic constituents, except magnesium, which is fairly constant, show considerable variation.

3. Contrary to expectation the hearts from individuals exhibiting arteriosclerotic changes or advanced in years are not conspicuous for unusually high calcium contents.

4. Potassium has been found too often in excess of sodium to leave any doubt that the relative proportion of these two elements is sometimes reversed. That this might affect cardiac contractility adversely and bring about cardiac standstill is a possibliity.

5. The His bundle in the ox heart contains apparently less potassium than the ventricular muscle, but this may be due to the relatively large amount of connective tissue as compared with the volume of the conducting fibers, the former containing little of the element.

Acknowledgment of the courtesy and cooperation of the Department of Pathology of the New Orleans Charity Hospital and of the suggestions and assistance of Dr. M. M. Wintrobe, of the Department of Internal Medicine of the Tulane School of Medicine, is herewith expressed.

\section{BIBLIOGRAPHY}

1. Lematte, L., Boinot, G., and Kahane, E., Bull. Soc. Chim. Biol., 1928, x, 553. Le Composition Minerale des Tissus de l'Homme et des Animaux.

2. Harrison, T. R., Pilcher, C. and Ewing, G., J. Clin. Invest., 1930, viii, 325. Studies in Congestive Heart Failure. IV. The Potassium Content of Skeletal and Cardiac Muscle.

Harrison, T. R., Calhoun, J. A. and Pilcher, C., South. Med. J., 1930, xxiii, 381. The Nature and Treatment of Cardiac Fatigue.

3. Norn, M., Skand. archiv. f. Physiol., 1929, lv, 162. Uber Kalium- und Natriumgehalt verschiedener Organe.

4. Matthews, A. P., New York, 1920, 3rd ed. p. 615. A Textbook of Physiological Chemistry. 
5. Howell, W. H., Am. J. Physiol., 1905-06, xv, 280. Vagus Inhibition of the Heart in Its Relation to the Inorganic Salts of the Blood.

Howell, W. H., and Duke W. W., Am. J. Physiol., 1908, xxi, 51. The Effect of Vagus Inhibition on the Output of Potassium from the Heart.

Howell, W. H., Am. J. Physiol., 1905-06, xv, 294. Conclusions.

6. Ringer, S., J. Physiol., 1884, v, 247. On the Mutual Antagonism between Lime and Potash Salts in Toxic Doses.

Ringer, S., J. Physiol., 1895, xviii, 425. Further Observations Regarding the Antagonism between Calcium Salts and Sodium, Potassium and Ammonium Salts.

Ringer, S., J. Physiol., 1883, iv, 29. A Further Contribution Regarding the Influence of the Different Constituents of the Blood on the Contraction of the Heart.

Ringer S , and Sainsbury, H., J. Physiol., 1894, xvi, 1. The Action of Potassium, Sodium and Calcium Salts on Tubifex Rivulorum.

7. Zwaardemaker, H., Arch. f. d. ges. Physiol., 1926-27, ccxv, 460. Uber das Erwachen des durch Kaliumentziehung zur Ruhe gekommenen Herzens durch die Bestrahlung des Radiums.

Zwaardemaker, H., Ergebn. d. Physiol., 1921, xix, 337. Utber die Bedeutung der Radioaktivität für das tierische Leben.

Zwaardemaker, H. and Zeehuisen, H., Arch. f. d. ges. Physiol., 1924, cciv, 144. Utber Ionenkonzentration und Frequenz der Herzwirkung.

Zwaardemaker, H., Arch. f. d. ges. Physiol., 1928, ccxviii, 354. Utber die Strahlungsstoffe im Herzen.

Zwaardemaker, H., J. Physiol., 1919-20, liii, 273. On Physiological Radioactivity.

Zwaardemaker, H., J. Pharm. and Exp. Therap., 1923, xxi, 151. The Biological Action of Potassium and Its Radioactivity (and many other articles of a like nature).

8. Treadwell, F. P. and Hall, W. T., New York, 1911, 3rd ed., pp. 436-438. Analytical Chemistry. Vol. II. Quantitative Analysis.

9. Goto, Kingo, J. Biol. Chem., 1918, xxxvi, 366. Mineral Metabolism in Experimental Acidosis.

10. Neubauer, H., Ztschr.f. Analyt. Chem., 1900, xxxix, 481. Eine abgekürzte Methode der Kalibestimmung in den Kalisalzen.

11. Kramer, B. and Tisdall, F. F., J. Biol. Chem., 1921, xlvi, 339. A Clinical Method for the Quantitative Determination of Potassium in Small Amounts of Serum.

12. Kramer, B. and Gittleman, I., Proc. Soc. Exp. Biol. and Med., 1926, xxiv, 241. The Gasometric Determination of Potassium.

13. Haberlandt, L., Ergebn. d. Physiol., 1926, xxv, 144. Die myogene Reizbildung und muskuläre Erregungsleitung Wirbeltierherzen. 
14. Demoor, J., (Cited from H. Zwaardemaker. Die Automatine als Strahlungsstoffe im Herzen.)

15. Zwaardemaker, H., Med. Welt., 1929, iii, 522. [Bioradioaktivität und Automatine.

Zwaardemaker, H., Proc. Acad. Sci. Amsterdam, 1928, xxxi, 258. Radiated Vitamin B and Automatin Action.

Zwaardemaker, H., Ztschr. f. Kreislaufsforschung, 1928, xx, 121. Die Automatine als Strahlungsstoffe im Herzen.

16. Macallum, A. B., J. Physiol., 1905, xxxii, 95. On the Distribution of Potassium in Animal and Vegetable Cells. 